\title{
Viscoelastic behavior of clay and slip used in ceramic
}

SouAD HASSENE DAOUADJI - Modeling and Computational Methods Laboratory, University of Dr. Moulay Tahar of Saida, Algeria

LARBI HAMMADI - Laboratory of Rheology, Transport and Treatment of the Complex Fluids, University of Science and Technology, Mohamed Boudiaf, Algeria - hammadi7280@yahoo.fr, larbi.hammadi@univ-usto.dz ABDELKRIM HAZZAB - Modeling and Computational Methods Laboratory, University of Dr. Moulay Tahar of Saida, Algeria

Érkezett: 2021. 01. 04. " Received: 04. 01. 2021. " https://doi.org/10.14382/epitoanyag-jsbcm.2022.2

\section{Abstract}

In this article we studied the effect of time and mass concentration on the viscoelastic behavior of a clay and slip used in the manufacture of ceramics from CERAMIR Algeria. The generalized model of Kelvin-Voigt is successfully applied to fit the creep and recovery data and to analyse the viscoelastic properties of clay and slip. The increase of time of creep-recovery shows a slow increase in Newtonian viscosity corresponding to the steady-state and instantaneous and delayed elastic compliance. On the other hand, the increase in the mass concentration of clay causes a rapid increase in the Newtonian viscosity corresponding to the steady-state and a decrease in instantaneous and delayed elastic compliance.

Keywords: clay, slip, ceramic, viscoelastic behavior

Kulcsszavak: agyag, agyagmassza kerámia, viszkoelasztikus viselkedés

\section{Introduction}

Clays are used in different branches of industry, such as in drilling fluids in order to control the viscosity and the yield stress of drilling muds [1-3], in ceramic industry [4], in the treatment of polluted water, for example in the adsorption of toxic organic compounds [5-6] and pharmaceutical application [7-9]. The clays are also employed as a thickener in stabilizing the oil-water emulsions [10-12]. Knowledge of rheological properties of clays plays a fundamental role in industrial application such as in a ceramic construction plant in order to determine good operating conditions of the pumps during ceramic manufacturing operations. Numerous researches have been devoted to the study of the rheological properties of suspensions of clays used in ceramics [13-14].The effect of a number of additives on rheological properties of slip of ceramic has been widely studied and it was the subject of many previous works [15] for example the sodium tripolyphosphate and sodium hexameto-phosphate [16], polyelectrolyt [17] and the non-traditional biopolymeric [18].

The main objective of this study is to achieve a fine characterization of the rheological properties of clay and slip used by the New Company of ceramic tiles of Remchi, Algeria in order to define a good condition of use of these clays for the operation of the pumps during the ceramic manufacturing operation in this factory.

\section{Materials and methods}

\subsection{Materials and sample preparation}

The Nedroma clay and slip were, recovered from the New Company of Ceramic tiles of Remchi, Algeria in powder form. The Nedroma clay as a powder was brought to the oven for 24 hours at $40^{\circ} \mathrm{C}$ for dehydration then crushed and passed away a sieve of $80 \mu \mathrm{m}$ to perform a size sorting compatible with
Souad HASSENE DAOUADJ

He is master in hydraulic, preparing the PHD thesis on Rheological and mechanical

characteristics of ceramic slips containing additives, at University Moulay Tahar of Saida under the direction of Professor Larbi HAMMAD and Professor Abdelkrim HAZZAB

Larbi HAMMADI

Larbi Hammadi is professor in Hydraulics (University of Science and Technology of Oran) and Engineer in Mechanical Engineering. Since 2002, he is Researcher Professor at the University of Science and Technology of Oran (USTOMB) where he exercised many teaching activities. He is actually the director of Laboratory of Rheology, Transport and Complex Fluids Treatment (LRTTFC) Oran Algeria. Significant results have been obtained in recent years, for example, in emulsions for pharmaceutical use, drilling muds, vases of dams, sewage treatment plant sludge's, ceramic, polymers and cavitation. See https://scholar.google.com/citations?user=L $\angle b B a N A A A A A J \& h=f r \& 0 i=a 0$

Abdelkrim HAZZAB Abdelkrim Hazzab, Professor and currently works in the Department of Civil and Hydraulic Engineering, University Moulay Tahar of Saida, Algeria.He heads a research group in the Modeling and Computational Methods Laboratory, Saida University, Algeria. His research focuses on subjects in hydraulics, in particular the study and modeling of floods, solid transport, and in materials science through rheology.

cone and plate geometry used for rheological measurements. Then the clay powder was dispersed in the required amount of distilled water by continuous magnetic stirring at room temperature during 24 hours in order to ensure their homogenization. Note that the slip is mixed in distilled water without sieving. The Table 1 shows the composition of slip used in this study.

\begin{tabular}{rlccccc}
$\begin{array}{c}\text { Nedroma } \\
\text { Clay }\end{array}$ & $\begin{array}{c}\text { Yellow } \\
\text { Clay }\end{array}$ & $\begin{array}{c}\text { Blue } \\
\text { Clay }\end{array}$ & $\begin{array}{c}\text { Feld- } \\
\text { spars }\end{array}$ & Sand & $\begin{array}{c}\text { Lime- } \\
\text { stone }\end{array}$ & $\begin{array}{c}\text { Fire- } \\
\text { clay }\end{array}$ \\
\hline $20 \%$ & $20 \%$ & $21 \%$ & $21 \%$ & $6 \%$ & $7 \%$ & $5 \%$ \\
Table 1 & $\begin{array}{l}\text { The composition of slip } \\
\text { 1. táblázat }\end{array}$ & Az agyagmassza összetétele
\end{tabular}

\subsection{Experimental set up}

The rheological measurements was performed by using a torque controlled rheometer (RS600 from Thermo-Fischer) connected to a temperature controlled water bath and equipped with a plate-cone geometry (diameter: $60 \mathrm{~mm}$; angle: 2 degree; gap: $105 \mu \mathrm{m}$ ). A solvent trap was placed around the measuring device in order to minimize solvent evaporation.

\section{Results and discussion}

\subsection{Effect of time on creep and recovery}

The study was carried out on a mass concentration of $50 \%$ in slip and 55\% in Nedroma clay with the following protocol: after a pre-shear at $100 \mathrm{~s}^{-1}$ for $60 \mathrm{~s}$ following a rest of $120 \mathrm{~s}$ after rest time we applied a constant stress of $10 \mathrm{~Pa}$, in the field of linear viscoelasticity, for different durations $(50 \mathrm{~s}, 150 \mathrm{~s}, 300 \mathrm{~s}$ and 700 s) while recording the evolution over time of the elastic 
complacency during the creep phase during each duration. At the end of each phase of the creep, the stress is instantly brought back to zero and the elastic compliance is measured during the recovery phase for different durations. Fig. 1 and 2 show the evolution of the elastic compliance of the slip and Nedroma clay as a function of time.

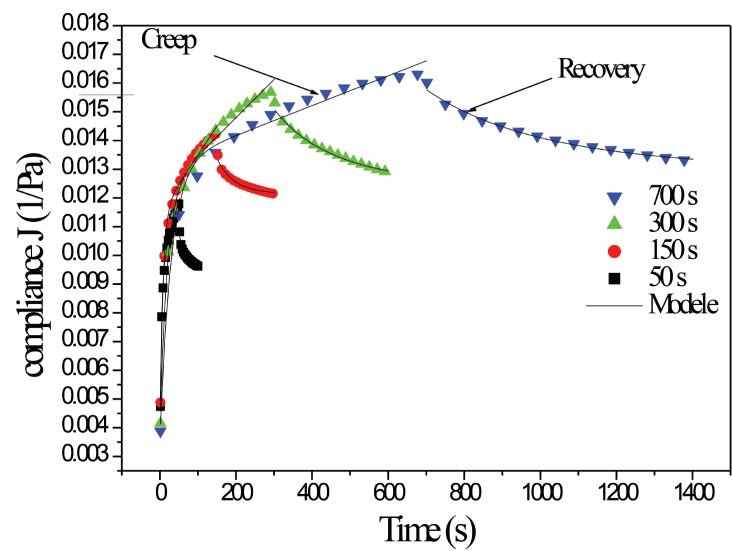

Fig. 1 Evolution of the elastic compliance of the slip as a function of time for different time applied

1. ábra Az agyagmassza rugalmassági tulajdonságának alakulása az idő függvényében

The viscoelastic behaviour were defined by correlating the results with the well-known viscoelastic models of Burger model or Generalized Kelvin-Voigt model, comprising the association in series of the Maxwell model and the KelvinVoigt

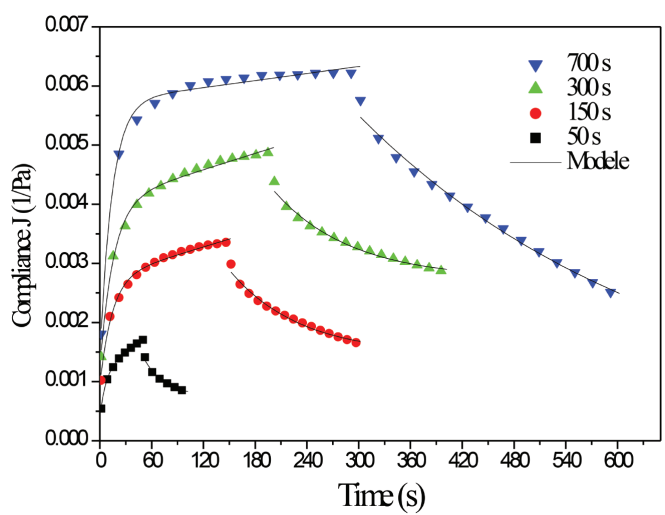

Fig. 2 Evolution of the elastic compliance of the Nedroma clay as a function of time for different time applied

2. ábra Nedroma agyag rugalmassági tulajdonságának alakulása az idő függvényében

The function of creep of this model is than written:

$J_{F}=J_{0}+\frac{t}{\mu_{0}}+\sum_{i=1}^{N} J_{i}\left\lceil-\exp \left(-\frac{t}{\theta_{i}}\right)\right]$

$\theta_{i}=\frac{J_{i}}{\eta_{i}}$

Whereas the recovery strain is given by:

$J_{R}=\frac{t_{1}}{\mu_{0}}+\sum_{i=1}^{N} J_{i}\left[\exp \left(\frac{t_{1}}{\theta_{i}}\right)-.\right] \exp \left(-\frac{t}{\theta_{i}}\right)$

where $J_{0}$ is the purely elastic contribution (or the instantaneous elastic compliance), $\eta_{0}$ is the purely viscous contribution, represented by the dashpot of the Maxwell model, i.e., the uncoupled or residual steady-state viscosity obtained from the creep curve at long times when the compliance curve is linear, $J_{i}$ is the contribution to retarded elastic compliance, $\theta_{i}$ is the retarded time, $\eta_{i}$ is the retarded viscosity and $t_{1}$ is the time where the stress is applied for $t \leq t_{1}$ and removed at $t=t_{1}$.

Fig. 3 and 4 show the evolution of the creep and recovery parameters as a function of applied time. The figures show an increase in instantaneous and delayed elastic compliance as well as Newtonian viscosity with increasing time [19]. The increase in instantaneous delayed elastic compliance and the Newtonian viscosity of the slip and the Nedroma clay with time indicating the transition from a viscoelastic regime to a viscous regime.

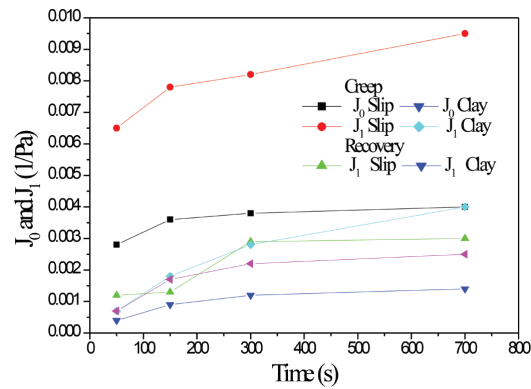

Fig. 3 Variation of the instantaneous elastic compliance $J_{0}$ and delayed $J_{1}$ of the Nedroma clay and slip of ceramic as a function of applied time

3. ábra A Nedroma agyag és agyagmassza $J_{0}$ és késleltetett $J_{1}$ pillanatnyi rugalmassági tulajdonságának változása az idő függvényében

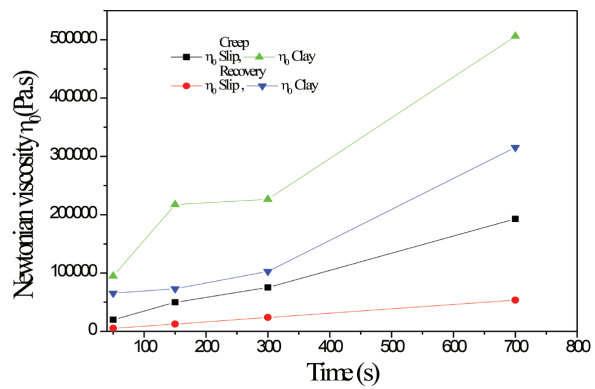

Fig. 4 Variation of Newtonian viscosity of the slip and the Nedroma clay as a function of applied time

4. ábra A Nedroma agyag és agyagmassza newtoni viszkozitásának változása az idő függvényében

\subsection{Effect of mass concentration on creep and recovery of clay}

The effect of mass concentration was performed only Nedroma clay for different concentration (40\%, 45\%, 50\%, 55\% and $60 \%$ ). After a pre-shear at $100 \mathrm{~s}$, for $60 \mathrm{~s}$ following a rest time of $120 \mathrm{~s}$, we applied a constant stress of $2 \mathrm{~Pa}$ during $180 \mathrm{~s}$ and recording the evolution of elastic compliance during the creep phase. After $180 \mathrm{~s}$ the stress is instantly reduced to zero and the elastic compliance is measured during the recovery phase for a time of 180s. Fig. 5 and 6 show the evolution of elastic compliance as a function of time for different concentration of clay. 


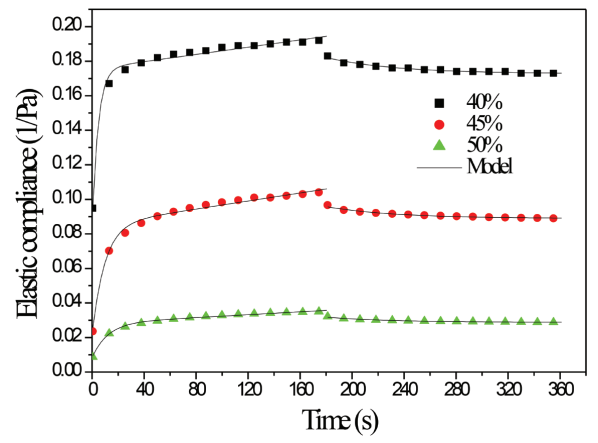

Fig. 5 Variation of elastic compliance of clay as a function of time (concentration: $40 \%, 45 \%$ and $50 \%)$

5. ábra Agyag rugalmassági tulajdonságában változása az idő függvényében (40\%, 45\% és 50\%-os kocentráció esetén)

We observed in Fig. 5 and 6 for weak concentrations of clay the deformation the clay during the creep phase is much greater and the system quickly relaxes during the recovery phase, we can explain this phenomena by weak liaisons of the internal structure of the clay on the other hand for high mass concentrations of clay the deformation during the creep phase becomes weak and the system slowly relaxes in this case the liaisons of the internal structure of the clay becomes rigid.

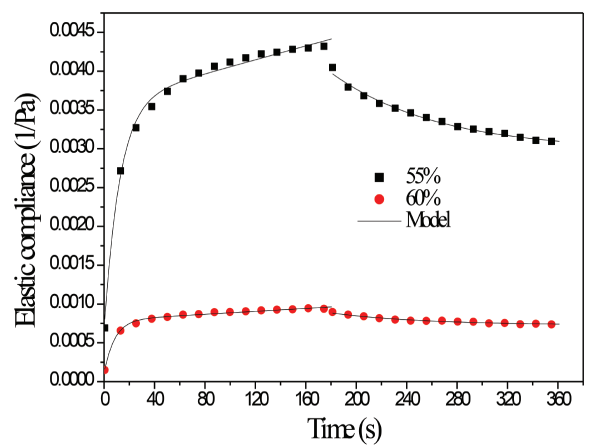

Fig. 6 Variation of elastic compliance of clay as a function of time (concentration: $55 \%$ and $60 \%$ )

6. ábra Agyag rugalmassági tulajdonságában változása az idő függvényében (55\% és 60\%-os kocentráció esetén

The evolution of elastic compliance as a function of time for different mass concentrations of clay was correlated using the generalized Kelvin-Voigt model (Eqs. 1 and 3). Fig. 7 shows a decrease in instantaneous elastic compliance ${ }_{0}$ and retarded elastic compliance $J_{1}$ of Nedroma clay with mass concentration. On the other hand, Fig. 8 shows an increase in Newtonian viscosity with the mass concentration of clay. Although these suspensions are initially formed from viscoelastic networks, they quickly disintegrate with concentration. A strong increase in Newtonian viscosity is observed for strong concentrations. In this case, the shear stress of $2 \mathrm{~Pa}$ is not sufficient to break weak particle-to-particle bonds of the clay and the suspension does not flow.

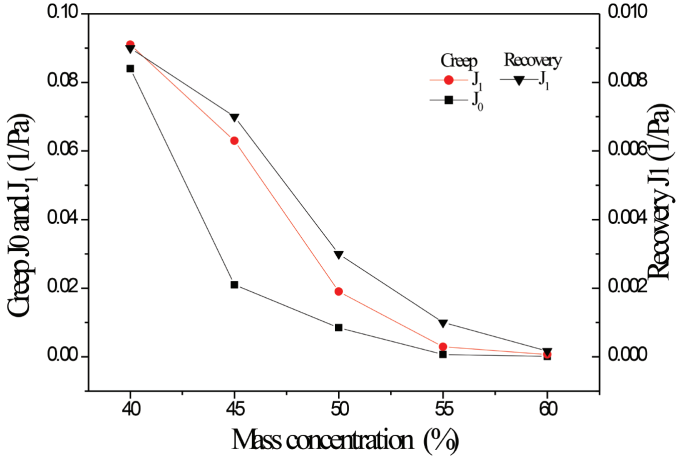

Fig. 7 Variation of instantaneous elastic compliance $J_{0}$ and retarded elastic compliance J of Nedroma clay as a function of mass concentration

7. ábra Nedroma agyag $J_{0}$ pillanatnyi rugalmas összeférhetöségének és $J_{1}$ késleltetett rugalmassági tulajdonságának változása az agyagtartalom függvényében

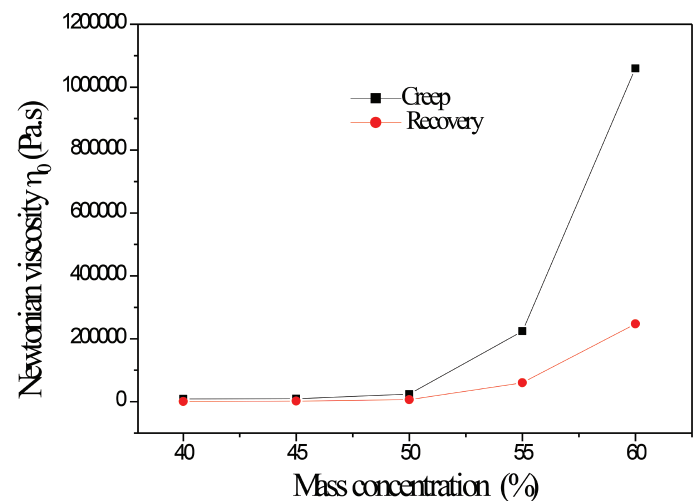

Fig. 8 Variation of Newtonian viscosity as a function of mass concentrations of clay 8. ábra A newtoni viszkozitás változása az agyagtartalom függvényében

\section{Conclusions}

The viscoelastic properties of clay and slip used in the manufacture of ceramic by New Company of Ceramic tiles of Remchi, Algeria at different times and mass concentration were studied. The generalized Kelvin-Voigt model was chosen to adjust the dependence of elastic compliance as a function of time for creep and recovery times range between $50 \mathrm{~s}$ and $700 \mathrm{~s}$ and mass concentrations range between $40 \%$ and $60 \%$ in solid particles. The increase in the creep-recovery applied time shows a slow increase in the Newtonian viscosity of the clay and of the slip corresponding to the steady state and of the instantaneous and delayed elastic compliance. For a creep-recovery time, the study shows that the concentration of $40 \%$ to $60 \%$ causes a rapid increase in the Newtonian viscosity of Nedroma clay. The study also shows a decrease in instantaneous elastic compliance $\mathrm{J}_{0}$ and delayed $\mathrm{J}_{1}$ of clay with mass concentration.

\section{References}

[1] BS., Bageri - AR., Adebayo- JAL., Jaberi - S., Patil (2020): Effect of perlite particles on the filtration properties of high-density barite weighted water-based drilling fluid. Powder Technology. Vol.360 pp1157-1166, https://doi.org/10.1016/j.powtec.2019.11.030.

[2] L., Hammadi - N., Boudjenane - M., Belhadri (2014) : Effect of polyethylene oxide (PEO) and shear rate on rheological properties of bentonite clay. Applied Clay Science. Vol. 99, pp. 306-311, https://doi.org/10.1016/j.clay.2014.07.016.

[3] R., Jain - V., Mahto (2015): Evaluation of polyacrylamide/clay composite as a potential drilling fluid additive in inhibitive water based drilling fluid 
system. Journal of Petroleum Science and Engineering Vol.133, pp. 612621, https://doi.org/10.1016/j.petrol.2015.07.009.

[4] MHA., Aziz -MHD., Othman-NA., Hashim- MR., Adam-A., Mustafa ( 2019): Fabrication and characterization of mullite ceramic hollow fiber membrane from natural occurring ball clay. Applied Clay Science. Vol. 177, pp. 51-62, https://doi.org/10.1016/j.clay.2019.05.003

[5] H., Han - MK., Rafiq - T., Zhou - R., Xu-O.,Mašek-X., Li (2019): A critical review of clay-based composites with enhanced adsorption performance for metal and organic pollutants. Journal of hazardous materials Vol.369, pp. 780-796, https://doi.org/10.1016/j.jhazmat.2019.02.003.

[6] AM., Awad- SM., Shaikh - R., Jalab - MH., Gulied -MS., Nasser -A., Benamor -S., Adham (2019) : Adsorption of Organic Pollutants by Natural and Modified Clays: A Comprehensive Review. Separation and Purification Technology. Vol. 228, pp. 115719, https://doi.org/10.1016/j.seppur.2019.115719.

[7] H., Kohay - II., Bilkis -YG., Mishael (2019): Effect of polycation charge density on polymer conformation at the clay surface and consequently on pharmaceutical binding. Journal of colloid and interface science. Vol.552, pp.517-527, https://doi.org/10.1016/j.jcis.2019.05.079.

[8] S., Gamoudi -E.Srasra (2017): Characterization of Tunisian clay suitable for pharmaceutical and cosmetic applications. Applied clay Science. Vol.146, pp.162-166, https://doi.org/10.1016/j.clay.2017.05.03.

[9] T., Thiebault - M., Boussafir - L., Fougère -E., Destandau -L., Monnin -C., LeMilbeau (2019) : Clay minerals for the removal of pharmaceuticals: Initial investigations of their adsorption properties in real wastewater effluents. Environmental Nanotechnology, Monitoring \& Management. Vol.12, pp. 100266, https://doi.org/10.1016/j.enmm.2019.100266.

[10] M., Khalid - A. Sultan-MN. Noui-Mehidi-A. Al-Sarkhi-O. Salim (2020): Effect of Nano-Clay Cloisite 20A on water-in-oil stable emulsion flow at different temperatures. Journal of Petroleum Science and Engineering. Vol. 184, pp. 106595, https://doi.org/10.1016/j.petrol.2019.106595.

[11] H., Nciri - M., Benna-Zayani-M., Stambouli -N., Kbir-Ariguib -M., Trabelsi-Ayadi M-V., Rosilio -JL., Grossiord ( 2009): Influence of clay addition on the properties of olive oil in water emulsions. Applied Clay Science. Vol.43, pp.383-391, https://doi.org/10.1016/j.clay.2008.11.006.

[12] SM., Shaikh -MS., Nasser - I., Hussein -A., Benamor-SA. Onaizi H., Qiblawey (2017): Influence of polyelectrolytes and other polymer complexes on the flocculation and rheological behaviors of clay minerals: A comprehensive review," Separation and Purification Technology. Vol.187, pp.137-161, https://doi.org/10.1016/j.seppur.2017.06.050.

[13] L., Hammadi (2018): Improving of the mechanical and rheological properties of slip of ceramic. Construction and Building Materials. Vol.173pp.118-123, https://doi.org/10.1016/j.conbuildmat.2018.04.035. [14] YA. Klimosh- IA., Levitskii (2004): Rheological properties of slips based on polymineral clays with electrolyte additives. Glass and Ceramics. Vol. 61, pp.375-378, https://doi.org/10.1007/s10717-005-0006-4.

[15] OA., Slyusar- V. M., Uvarov (2017): Effect of complex additives on ceramic slip mobility. Glass and Ceramics. Vol.74, pp.110-111, https://doi.org/10.1007/s10717-017-9940-1.

[16] A. Slyusar -O., Slyusar -N. Zdorenko (2008): Rheological properties and critical structure-forming concentration of kaolin suspensions with complex additives. Glass \& Ceramics. Vol. 65, pp.285-286, https://doi.org/10.1007/s10717-008-9060-z.

[17] P., Marco - J., Labanda-J.Llorens (2004): The effects of some polyelectrolyte chemical compositions on the rheological behaviour of kaolin suspensions. Powder Technology. Vol.148, pp. 43-47, https://doi.org/10.1016/j.powtec.2004.09.019.

[18] T., Žižlavský- M., Vyšvařil-P., Rovnaníková (2019): Rheology of natural hydraulic lime pastes modified by non-traditional biopolymeric admixtures. Epitoanyag-Journal of Silicate Based \& Composite Materials. Vol.6, pp. 204-209, https://doi.org/10.14382/epitoanyag-jsbcm.2019.36

[19] MMS., Quiambao-DD.,Laplana- MID.,Abobo- AG., Jancon-SD., SalvadorHC., Siy (2019): Rheological characterization of the curing process for a water-based epoxy added with polythiol crosslinking agent. EpitoanyagJournal of Silicate Based \& Composite Materials. Vol.71,No.5,pp.162-167, https://doi.org/10.14382/epitoanyag-jsbcm.2019.28.

Ref.:

Hassene Daouadji, Souad - Hammadi, Larbi - Hazzab, Abdelkrim: Viscoelastic behavior of clay and slip used in ceramic Építőanyag - Journal of Silicate Based and Composite Materials, Vol. 74, No. 1 (2022), 9-12. p. https://doi.org/10.14382/epitoanyag-jsbcm.2022.2

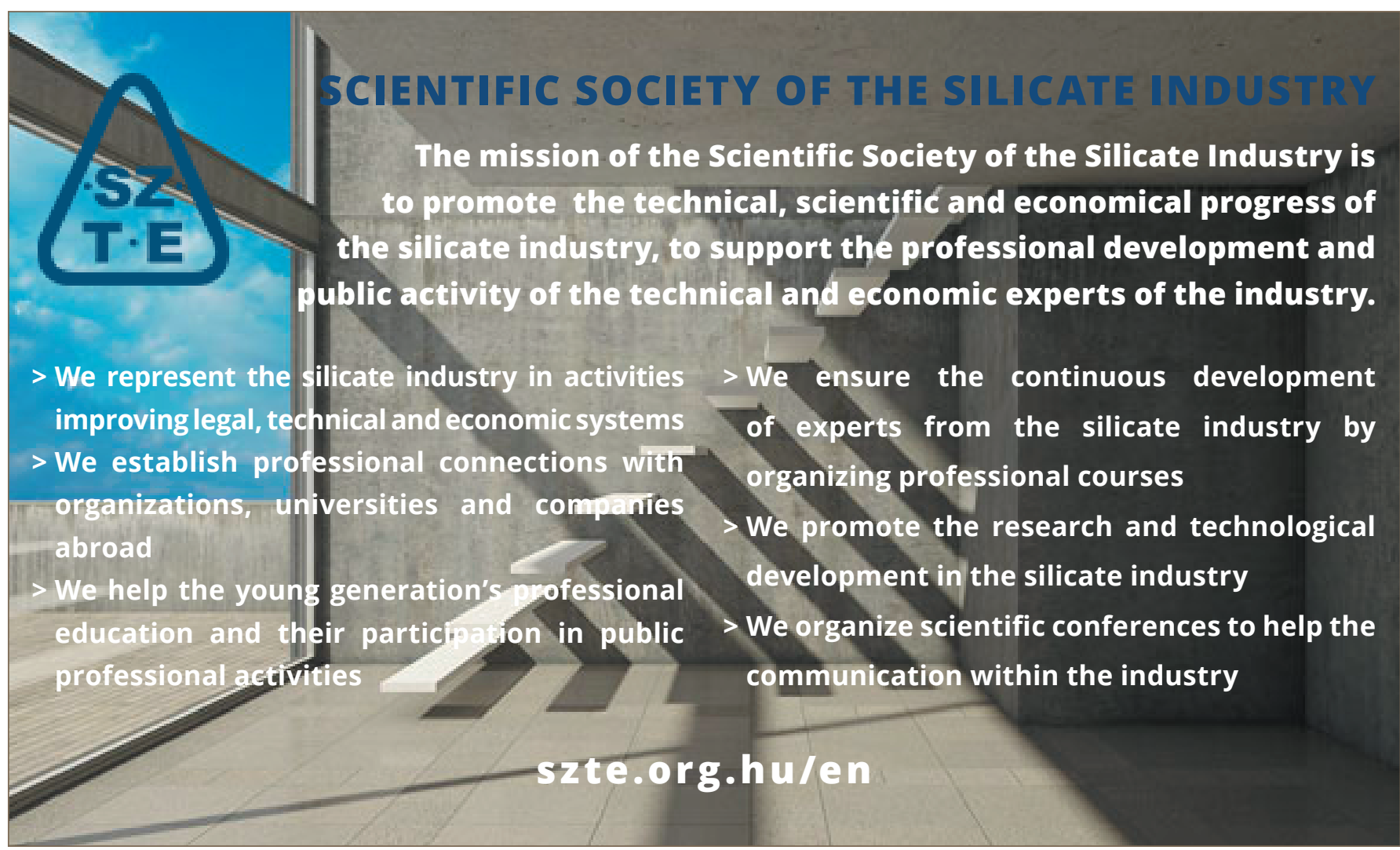

